ANTE BUKŠA, Ph.D.

E-mail: buksa@pfri.hr IVICA ŠEGULJA, Ph.D.

E-mail: is@pfri.hr

VINKO TOMAS, Ph.D.

E-mail: tomas@pfri.hr

University of Rijeka, Faculty of Maritime Studies

Studenska 2, HR-51000 Rijeka, Republic of Croatia
Transport Engineering

Preliminary Communication

Accepted: Mar. 20, 2009

Approved: Mar. 19, 2010

\title{
ADJUSTMENT OF MAINTENANCE APPROACH FOR IMPROVED OPERABILITY AND SAFETY OF SHIP NAVIGATION
}

\begin{abstract}
By adjusting the maintenance approach towards the significant components of ship's engines and equipment, through the use of operational data from the ship machinery's daily reports, higher operability and navigation safety can be achieved. The proposed maintenance adjustment model consists of an operation data analysis and risk analy sis. The risk analysis comprises the definition of the upper and the lower risk criterion, as well as the definition of a risk index. If the risk index is higher than the lower risk criterion, the component is significant, while it is not significant and has an acceptable risk index if the risk index is lower than the lower risk criterion. For each significant component with a risk index found to be "unacceptable" or "undesirable", an efficient maintenance policy needs to be adopted. The as sessment of the proposed model is based on data regarding the power engine original operation throughout a 13-year period. The results of engine failure examinations reveal that the exhaust valve is the most vulnerable component with the highest rate of failure. For this reason the proposed model of adjusting the maintenance approach has been tested on the exhaust valve sample. It is suggested that the efforts to achieve higher ship operability and navigation safety should go in the direction of periodical adjustments of the maintenance approach i.e. choosing an efficient maintenance policy by reducing the risk indices of the significant engine components.
\end{abstract}

\section{KEY WORDS}

maintenance adjustment approach, risk analysis, risk index, lower risk criterion, upper risk criterion, significant components, ship navigation

\section{INTRODUCTION}

The ships that are designed and built to satisfy the classification rules and the IMO regulations have an acceptable level of reliability for safe navigation. Unplanned intermissions and engine failures that can result from inadequate maintenance may cause ad- ditional costs (ships are not in operation for a certain period of time). Every hour of intermission brings high expenses to the ship-owner and the maintenance experts' task is to do their best to avoid the unplanned intermission or to reduce its duration. Since the loss of ship propulsion, even for a short time, must be avoided, ship-owners use more rigorous, redundant designs to reduce that risk. This leads to increasing the costs of the ship's life cycle.

To enhance the operability and safety of navigation it is necessary to reduce the risk of the failure-effect on the significant machinery components. The maintenance approach by timing which is generally used aboard ships does not represent the most efficient maintenance approach. By adjusting the maintenance approach to increase the operability and safety of navigation, the suggested producers intervals can be modified because of certain factors that influence the state and performance of a component. Adjustment of the maintenance approach of the most significant components based on the real operational data is more reliable than the design of the initial maintenance concept for a new ship.

\section{ADJUSTMENT OF THE MAINTENANCE APPROACH}

The model for the adjustment of the maintenance approach with the aim of decreasing the risk index of the significant components of the propulsion engine is shown in Figure 1. It is carried out in two phases:

1. Ship - the machinery behaviour is recorded and a database is created. Daily propulsion reports are registered in the log book during 24 hours. Data on failures and maintenance operations are recorded, as well as the duration of the intermission period.

2. Office - the database is used, data analysis is performed and the maintenance approach is adjusted. 
2.1 Operation data analysis - the work time, intermission, maintenance, failure distribution and failure rate are displayed. Within the identified components in the failure mode analysis the significant modes and failure effects are identified. For the given component samples, along with the parameters of position $\left(t_{0}\right)$, shape $(\beta)$ and the Weibull distribution rate $(\eta)$, the predictability of the failure $(p)$ is defined. The preventive maintenance interval equals the sum of position and rate parameters $\left(t_{0}+\eta\right)$ for the analyzed components. The parameter $t_{0}$ is either the threshold parameter, the guarantee time or the minimum life of the component. Predictions of the minimal life can be obtained by interviewing the experts. However, since occasional failures occur during the whole work cycle of the system, and the experts' answers are mostly uncertain, it is safe to conclude that in the case of older machinery $t_{0}=0$. In such a case, the Weibull distribution has two parameters $(W(\eta, \beta))$ and the ratio's parameter represents the preventive maintenance interval $(\eta=$ mean life).

2.2 Risk analysis - comprises the definition of the URC (Upper Risk Criterion) and LRC (Lower Risk Criterion), as well as the RI (Risk Index). Risk can be defined as the expected loss, connected with the occurrence of an undesirable event, i.e. it is mathematically the "probability of $x$ consequences". The consequence (expected loss) is expressed in terms of SI (Significance Index), whereas the probability (expected event) is expressed by the ELFF (Expected Life Failure Frequency) [1].

The risk index is defined by the product of the significance index and the expected life failure frequency.

$R I=S I \cdot E L F F$.

There are two categories of significance: safety and operation.

The safety risk index:

$R I(s)=S I(s) \cdot E L F F$.

The operation risk index:

$R I(0)=S I(0) \cdot E L F F$.

The significance index SI shows the magnitude of the expected loss which is connected with an undesir-

Table 1 - The significance index [1] able event. The index shows the significance on the scale $(0 \rightarrow 1)$. Unit $(1)$ represents disaster, while zero (0) means an effect without significance (Table 1).

The Expected Life Failure Frequency (ELFF) represents the expected number of failures that will be removed by a repair action, and according to [1] is defined as:

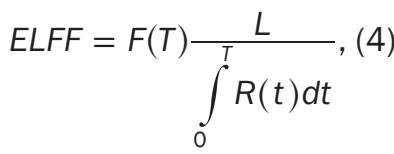

where $F(T)$ is the failure probability within maintenance interval $T$, while $L$ is the life of the component. If the preventive maintenance is not defined for a certain component, the maintenance interval $T$ is equal to the component's life $L$, and the equation (4) takes the following form:

$$
E L F F=F(L) \frac{L}{\int_{0}^{L} R(t) d t} .
$$

In the case of MTTF (Mean Time to Failure) being much shorter than the component's life $L(M T T F<<L)$, one can estimate that:

$$
\begin{aligned}
& \int_{0}^{L} R(t) d t \Rightarrow \int_{0}^{\infty} R(t) d t=\text { MTTF } \\
& F(L) \Rightarrow 1 \\
& E L F F \Rightarrow \frac{L}{\text { MTTF }} .
\end{aligned}
$$

The installed component is in use until failure occurs, and is then regenerated. The condition after the regeneration is considered as new.

The aim of the risk index is to define equal risk effects with regards to safety and the operation. These are the URC and LRC curves that connect the points of equal risk and determine the acceptable, undesirable and unacceptable zones of risk index (Figure 2).

Depending on the consequences of the failure, the components may be significant or non-significant. The lower risk criterion (LRC) separates the significant components from the non-significant ones and is one hundred times more reliable than the upper risk criterion $(\mathrm{URC}=100 \mathrm{LRC})$. The significant components are

\begin{tabular}{||c|l|c|l||}
\hline \hline Class & \multicolumn{1}{|c|}{ Magnitude } & SI & \multicolumn{1}{c||}{ Possible failure effects } \\
\hline \hline \multirow{4}{*}{ Safety } & catastrophic & 1 & loss of ship, environmental catastrophe \\
\cline { 2 - 4 } & critical & 0.1 & critical injury, major ship damage \\
\cline { 2 - 4 } & severe & 0.01 & minor injury, damage to ship, secondary damage \\
\cline { 2 - 4 } & marginal & 0.001 & possible injury, possible damage to ship \\
\cline { 2 - 4 } & negligible & $<0.0001$ & no injury, no possible damage to ship \\
\hline \multirow{3}{*}{ Operation } & not available & 0.01 & the ship is unavailable for operation during some days \\
\cline { 2 - 4 } & partially available & 0.001 & the ship is unavailable for operation during some hours \\
\cline { 2 - 4 } & reduced performance & 0.0001 & the ship operates with reduced performance \\
\cline { 2 - 4 } & available & $<0.00001$ & the ship is fully operational \\
\hline
\end{tabular}




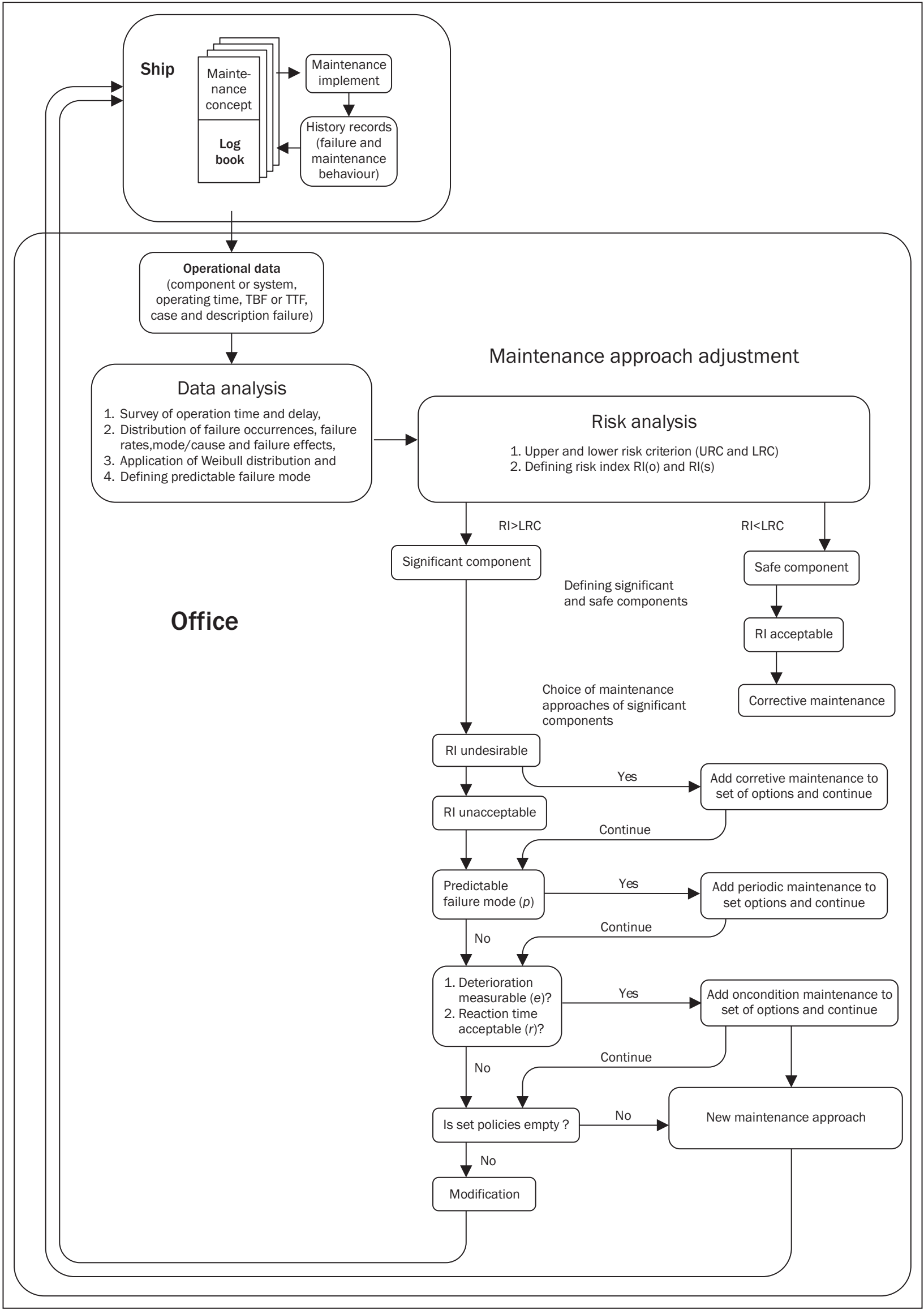

Figure 1 - Model for maintenance approach adjustment 


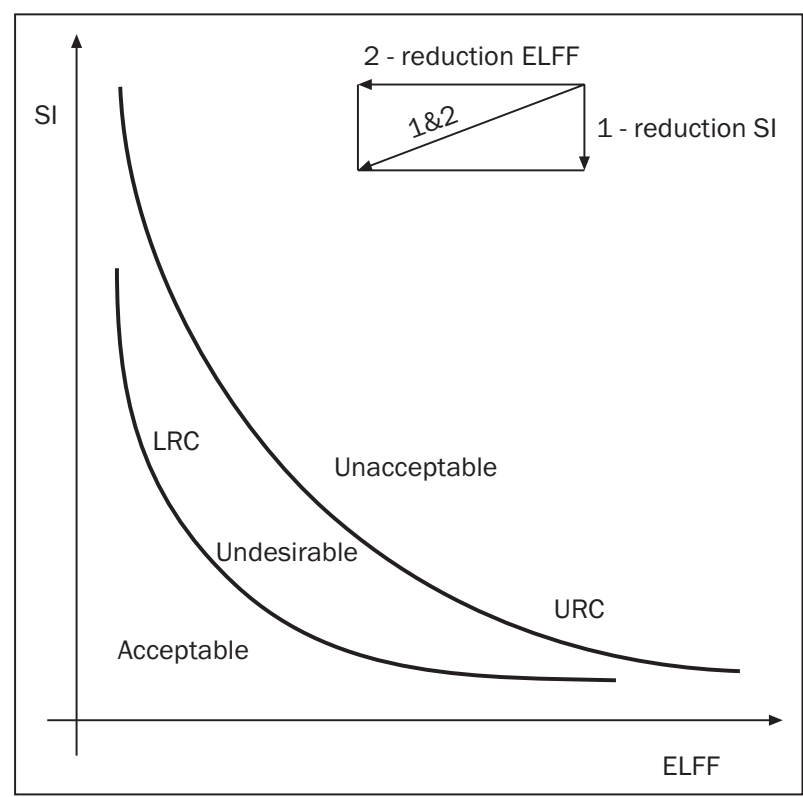

Figure 2 - Domain risk index [1]

those that have significant influence on the safety or the operation (or the price of repair), so their risk index may be undesirable or unacceptable. In the significant component there is at least one failure combination of mode/cause, whose safety or operation risk index is higher than LRC. On the other hand, in the non-significant or safe component the risk index is below LRC and that risk index is acceptable.

Once the functional failure appears, its effects always have the same meaning. The reduction of the risk index may be achieved by the adjustment of the maintenance approach or by a modification of the installed component. The maintenance can affect the failure frequency; however, it cannot change the significance of the failure effect. In other words, the maintenance actions reduce the risk index by reducing ELFF. In the figure it is shown by direction 2 .

The significance of the failure effect may be reduced by a modification of the installed component. A change in the installed component geometry alters the behaviour of the failure, which can lead to a different failure effect and a different significance. This is shown in Figure 2 by direction 1 (significance reduction). The combination of $1 \& 2$ is also possible.

For each significant component identified in the risk analysis an efficient maintenance policy must be chosen. For the failure modes effects having the risk index in an unacceptable zone, preventive maintenance (PM) could be required to reduce the risk. If that is not possible, a modification will be required. The components with the risk index within the acceptable zone will be given the corrective maintenance (CM). When the risk index is undesirable, corrective maintenance must be considered as a possibility of an efficient maintenance policy. Later on, during the optimization of the costs, it will be decided whether the $\mathrm{CM}$ can be applied (in case the CM costs are lower than the PM costs).

If the risk index is unacceptable, preventive maintenance is not suitable. The risk index can be reduced to an acceptable level by a mere modification, thus reducing both the significance and the risk index.

Predictability $(p)$ in risk analysis shows whether the failure behaviour is suitable for control by means of periodical actions. The predictability indicates the possibility of foreseeing the time between the failure (TBF) and the time to failure (TTF). According to [1], if the failure rate is decreasing (DFR - decreasing failure rate) or constant (CFR - constant failure rate), the predictability equals zero $\left(p=0, \beta \leq 1\right.$ and $\left.t_{0}=0\right)$. In such cases the periodical maintenance is inefficient. Moreover, if the predictability is low $(0<p \leq 0.5$, $1<\beta<2$, and $t_{0}=0$ ), periodical preventive maintenance may be taken into consideration, but an "oncondition PM" is more desirable. A periodical PM is selected in the case of high predictability $(0.5 \leq p \leq 1$, $\beta \geq 2$ and $t_{0}=0$ ), when a significant increasing failure rate (IFR) is present. Evidence (e) and time of reaction $(r)$ in the selected maintenance approach for the significant component will determine the decision regarding the "on-condition PM" approach. Evidence (e) shows whether the operator may notice the deterioration development [1]. If so, the time of reaction is used as a second criterion. If the time of reaction is zero or very short (totally unexpected or almost totally unexpected failure) the "on-condition PM" option will be rejected.

\section{POWER ENGINE FAILURES}

The paper [2] presents the research of power engine failures, based on original data from the power engine daily reports during a 13-year period. The power engine is a MAN 7L Diesel engine of 400/500 power 2200kW (3000hp), a 400mm cylinder diameter, number of cylinders 7 and a piston stroke of $540 \mathrm{~mm}$ [3]. The engine daily reports were registered in the log book [4], which was kept every day from 00 to 24 hours either during navigation or the stay in the port.

Data analysis comprises 61,600 operative hours of the power engine [2]. During the 13-year period the total number of intermissions was 155 and the total intermission time $\approx 386$ hours, i.e. approximately 2.5 hours per intermission. The exhaust valve, the injector valve and the fuel oil pump (high pressure pipe) are the components with the highest number of intermissions. The injector valve had the highest number of replacements with an average replacement time of 0.5 hours, followed by the exhaust valve with an average replacement time of 2.5 hours.

From a total of 65 intermission notes regarding failure of the injector valve, only four cases of irregular 
state have been recorded, which proves that the injector valve was replaced preventively. From 62 replacements of the exhaust valves (in couple), 30 failures were registered (combustion, blow-out, erosion, leakage, deposits), which accounts for approximately $50 \%$ of the cases. Valve combustion was the most frequent failure (19 cases), followed by valve bursting (5).

Total failure rate of the power engine is $\lambda=1.2822 \cdot 10^{-3}$ [hour $^{-1}$ ] and it is approximately $22.8 \%$ higher than that registered for the Japanese power engines, where it is $\lambda=0.989 \cdot 10^{-3}$ [hour $^{-1}$ ] according to the SRIC (Ship Reliability Investigation Committee) [5,6]. SRIC has made a study covering 231 ships in the 13-year period.

The highest failure rate was found for the exhaust valve, which amounted to $\lambda=0.4870 \cdot 10^{-3}$, while, according to the SRIC, it was $\lambda=0.4218 \cdot 10^{-3}$ (exhaust valves, fuel oil pump). As far as data integrity is concerned in the study, the exhaust valve is the most accurately described of all the analysed components. The results of the exhaust valve sample are shown in Table 2. The position parameter $t_{0}=0$ means that the failures are possible after the installation of the exhaust valve. The maintenance interval for the whole exhaust valve is $\eta=3333$ hours, whereas it is $\eta=3447$ hours for the valve and the valve seat. The predictability of failure for the valve and the valve seat is $p=0.51$ (51\%). It is a case of high predictability $\left(\beta \geq 2, p>0.5\right.$ and $\left.t_{0}=0\right)$, when the exhaust valve indicates significant IFR.

According to [2], the exhaust valve FMCC has a very clear basic failure effect (spindle malfunction $\Rightarrow$ exhaust valve failure $\Rightarrow$ accelerated deterioration of the valve seat). Hence, the valve and the valve seat show the failure effect: "no closure", which results in "bad combustion and decrease in cylinder power".

\section{DETERMINATION OF UPPER AND LOWER RISK CRITERIA}

The fault tree analysis is the basic method for the analysis of safety systems. The analysis starts with defining the undesirable event, then proceeds towards the bottom in order to find the failure of the system elements that might cause the undesirable event. The undesirable or the so-called top event will be the loss of the ship ( $\mathrm{SI}=1$ ), and the events at the bottom are the FMCCs with the critical failure effects. The probability of the ship loss due to a propulsion engine failure is obtained from the expression
$F(L)=1-e^{-A F R \cdot L}=1-e^{-0.001 \cdot 20}=0.0198$,

where AFR is the Average Failure Rate of the component ( $A F R=0.0028 \cdot 0.36 \cong 0.001$ per year $)$ and $L$ is the lifetime of the ship ( $L=20$ years). The average total loss amounts to $0.28 \%$ of the world's shipping tonnage [7], and according to [8] 36\% of the failures are caused by the propulsion engines.

Two events in the failure tree analysis may lead to ship loss (Figure 3):

1. Fire or explosion, an event caused by a technical failure of the propulsion engine, including the possibility of firing mechanisms. Firing is possible only if the components are in operation (estimated at 75\%) and if the leakage of fuel oil or lubricant occurs.

The leakage of fuel oil in the propulsion engine can occur either on the fuel system or on the lubrication system. Leakage on the fuel system can occur on the high-pressure pipe or on the injector valve. Analysing the data published in [2] and consulting the experts, it can be concluded that the fuel oil leakage on the high pressure pipe can occur due to a failure of the nonreturn valve, the piston or the juncture with the high pressure pipe. On the injector valve the fuel leakage may occur on the juncture of the fuel high pressure pipe or due to a needle malfunction. Furthermore, from the examination of failures on the propulsion engine type MAN 7L 400/500 three possible cases of leakage on the lubrication system were noted. These are the failures at $45788^{2}, 72446^{3}$ and $76256^{4}$ hours of engine work, where condition "leakage" was recorded. The fuel or lubricant leakage will only be critical if it leaks onto a hot surface. The estimated probability of that being the case is 0.01 .

From the above mentioned analysis it arises that there are five critical FMCCs on the fuel oil system per cylinder and 35 FMCCs on the propulsion engine fuel system. Adding to this number the three cases of the Iubrication system, there are a total number of 38 critical propulsion engine FMCCs.

2. Functional loss in critical conditions is the case of steering loss, with two critical FMCCs: one for the steering gear and the other for the rudder. In the case of critical conditions, weather accounts for an average loss of $2.6 \%$, a ship wreckage for $9.3 \%$ and collisions for $8.7 \%$ of losses, while the average annual loss of the world shipping tonnage is $0.28 \%$ (weather $0.0028 \cdot 0.026=0.00007$, ship wreckage $0.0028 \cdot 0.093 \cong 0.00026$ and collision $0.0028 \cdot 0.087 \cong 0.00024$ ) [7].

Table 2 - Results of the exhaust valve sample [2]

\begin{tabular}{||c|l|l|c|c|c|c|c||}
\hline \hline FMCC $^{1}$ & \multicolumn{1}{|c|}{ Component } & Failure mode/cause & $\beta$ & $t_{0}$ & $\eta$ & MTBF & Predictability $p$ \\
\hline \hline$(1)$ & Exhaust valve (complete) & Wear/usage & 2 & 0 & 3333 & 2943 & 0.46 \\
\hline$(16)$ & Valve and valve seat & Valve burned out/usage & 2.23 & 0 & 3447 & 3046 & 0.51 \\
\hline
\end{tabular}




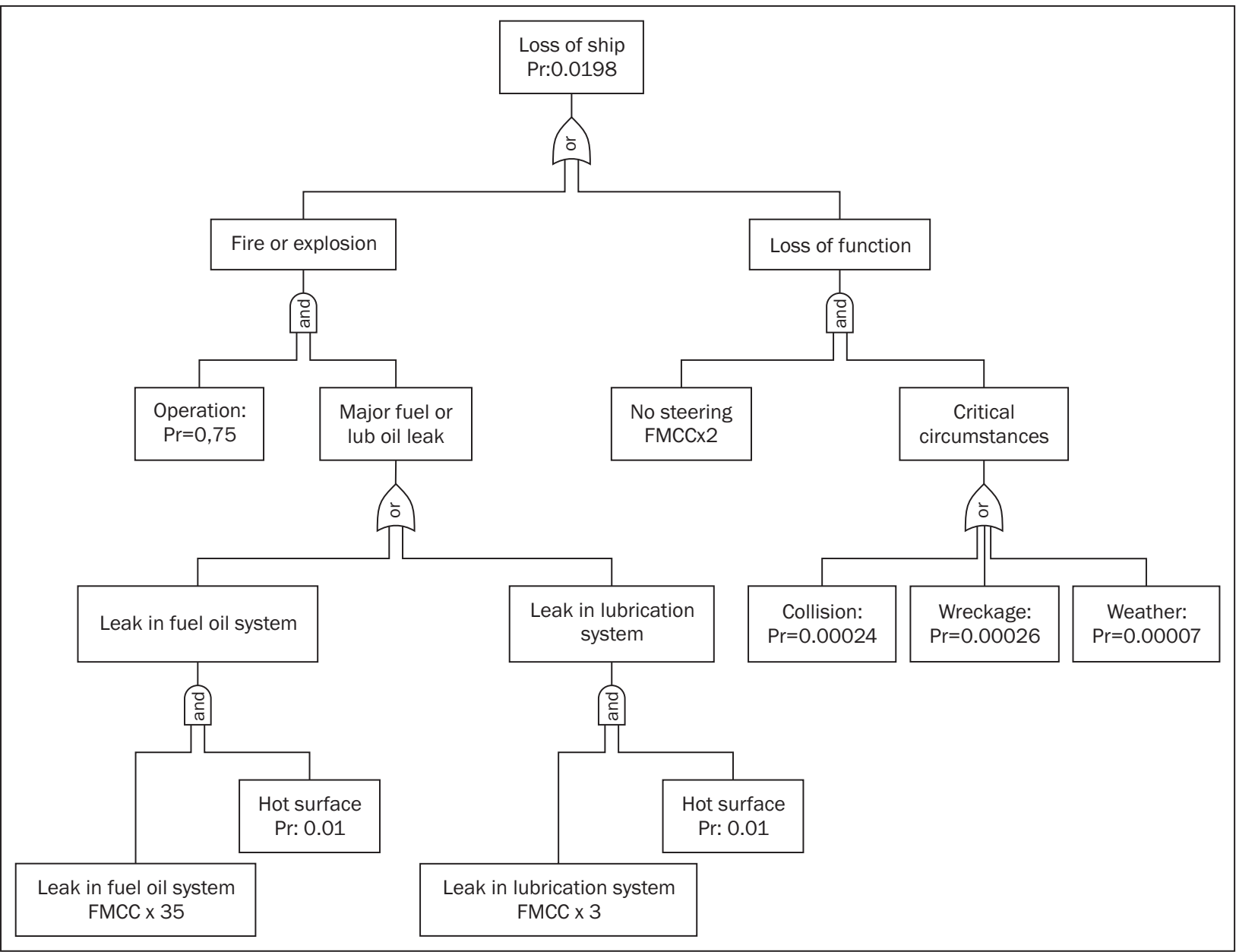

Figure 3 - Failure tree

For the fault tree solving, the following equations are used:

"and": $P(A \cap B)=P(A) \cdot P(B)$

"or": $P(A \cup B)=P(A)+P(B)-P(A) \cdot P(B)$.

The logical "and" is calculated as a cross-section probability, while the "or" is estimated as the union of the event probability. For parallel events, the "or" members corresponding to the cross-section are not considered in the estimate of probability of the fault tree analysis because they are small in size. By neglecting these members the result of the analysis gives a somewhat higher value of the event probability in the catastrophe tree. The seeking value ELFF of the catastrophic events $(S I=1)$ for the bottom level is represented by the unknown $x$.

$$
\begin{aligned}
& (35 x \cdot 0.01+3 x \cdot 0.01) \cdot 0.75+ \\
& \quad+2 x \cdot(0.00024+0.00026+0.00007)= \\
& \quad=0.0198
\end{aligned}
$$

$x=0.069$

Value $x \approx 0.07$, obtained from the equation is the DLFF of the catastrophic event. It is used for determining the upper and lower criterion of the risk index.

The upper risk criterion for $S I=1$ is:

$U R C=E L F F \cdot S I=0.07 \cdot 1=0.07$
The URC explains that the critical FMCC must have an average failure rate smaller than 0.07 per year or $\approx 8 \cdot 10^{-6}$ per hour.

This criterion is now estimated for the less significant events (reduced performance - without damage to the ship or the environment). In that case $S I=0.0001$ (Table 1), is obtained:

$E L F F=\frac{U R C}{S I}=\frac{0.07}{0.0001}=700$

Equation (12) shows the limit value of a non acceptable risk, obtained for the FMCCs with the failure effects of the reduced performance. The less significant failure effect is non acceptable if it occurs more than 700 times during the planned lifetime. This is more than 35 times per year or 3 times per month.

The lower risk criterion separates the significant components from the non significant ones and is one hundred times more reliable than the URC, which means:

$$
\begin{aligned}
& L R C=\frac{U R C}{100}=0.0007 \\
& \text { It follows that: } \\
& \text { upper risk criterion URC }=7 \cdot 10^{-2} \text { - } \\
& \quad \text { - unacceptable } / \text { undesirable } \\
& \text { lower risk criterion } L R C=7 \cdot 10^{-4} \text { - } \\
& \text { - undesirable / acceptable }
\end{aligned}
$$


Table 3 - Results of exhaust valve risk index

\begin{tabular}{||c|l|c|c|c|c|c||}
\hline \hline FMCC & \multicolumn{1}{|c|}{ Component } & SI(s) & SI(o) & ELFF & $R I(s)$ & $R I(0)$ \\
\hline \hline$(1)$ & Exhaust valve (complete) & 0.0001 & 0.001 & 25.5 & 0.00255 & 0.0255 \\
\hline$(16)$ & Valve and valve seat & 0.0001 & 0.001 & 24.6 & 0.00246 & 0.0246 \\
\hline
\end{tabular}

Table 4 - Results of exhaust valve maintenance approach adjustment

\begin{tabular}{|c|c|c|}
\hline $\begin{array}{l}\text { The choice of main- } \\
\text { tenance approach }\end{array}$ & $\begin{array}{l}\text { Preventive } \\
\text { Maintenance }\end{array}$ & $\begin{array}{l}\text { 1. Periodic PM; high predictability: } p=0.51, \beta=2.23 \text { (significant IFR) } \\
\text { (suggested maintenance interval is } 3400 \text { hours) } \\
\text { 2. Discrete on-condition PM: } \\
\quad \text { = I (inspection) } \\
\text { Reaction time is acceptable: } r>0 \text { (5-50 sati) } \\
r_{\mathrm{sr}}=\left(r_{\max }+r_{\min }\right) / 2=27.5 \mathrm{hs}\end{array}$ \\
\hline
\end{tabular}

\section{MAINTENANCE ADJUSTMENT APPROACH FOR THE EXHAUST VALVE}

Since the exhaust valve is the most vulnerable propulsion engine component with the highest failure frequency, the proposed adjustment model for the maintenance approach will be shown on the exhaust valve sample.

As the exhaust valve is significant in terms of safety and operation, it is necessary to define the significance indices of safety and operation. The operation significance indices of the exhaust valve are $S I(0)=0.001$ because the failure effects include the unavailability of the ship during a few hours (Table 1). As far as safety is concerned, its significance index is $S I(s)=0.0001$ (with no accident and no damage to ship or environment).

The failure frequency in the life of the ELFF component will be obtained following the expression (6) if the component's lifetime is divided by the average time between the MTBF failures according to Table 2 . The lifetime of the valve is 75,000 hours (twice reconditioned). The valve and the valve seat failed 24 times and the complete exhaust valve 25 times during the planned operation period. The results of risk analysis are shown in Tables 3 and 4.

According to Figure 4 the exhaust valve risk index is in the undesirable region (RI undesirable). It means that the exhaust valve is a significant component, having two failure mode combinations with the risk indices (safety and operation) higher than the $L R C$. According to the model, when risk index is in the undesirable zone, a CM is added as a possible efficient maintenance approach.

In the case of the mentioned exhaust valve, because of its high predictability $(p=0.51, \beta=2.23$ and $t_{0}=0$ ), the preventive periodical maintenance with the maintenance interval shifted to 3500 hours ( $\eta=3447$ hours, Table 2$)$ is strongly advised. On the other hand, the maintenance interval (opening, repairing and assembling all exhaust valves) for the expecting wear-out of the exhaust valve is planned according to [3] every 5000 hours.

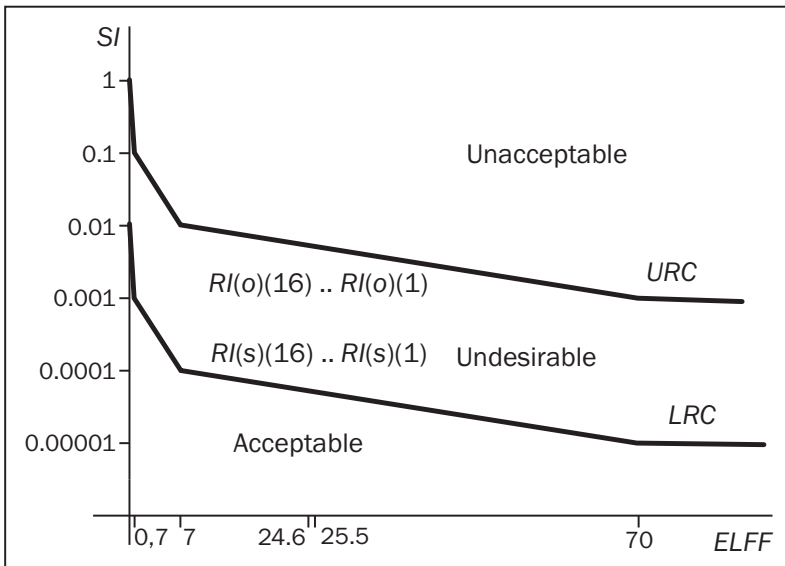

Figure 4 - Graphic survey of exhaust valve risk index

Evidence (e) (noticing a deterioration) is the main indicator of whether to apply inspections or continued monitoring. As a potential failure can be noticed only by disassembling and examining the valve, it is necessary to opt for inspection (I). The reaction time ( $r$ ) is the average time between potential and functional failure. According to the interviews with experts it has been estimated that the reaction time for the exhaust valve is between 5 and 50 hours [2]. The reaction time is acceptable since it is long enough to enable maintenance action at the moment when it is necessary. The result of the maintenance adjustment approach for the exhaust valve in order to reduce its risk index by reducing the ELFF is presented in Table 4.

\section{CONCLUSION}

Longer and safer navigation is achieved with the adjustment of maintenance approach for the significant components, i.e. by choosing an efficient maintenance policy by reducing the failure frequency in the component lifetime or by a modification: decrease of significance of the failure effect on safety and operation.

The results of the analysis of the propulsion engine failures have shown that most failures occurred on the injection valve and the exhaust valve. The most vulnerable propulsion engine component is the ex- 
haust valve with the highest failure rate, and the most common failure mode is the valve and the valve seat burning. Through the analysis the propulsion engine failures, using the fault tree analysis, where the top event is the ship loss and the events at the bottom are the failure modes with the critical failure effects, it is possible to define the upper risk criterion. The lower risk criterion is one hundred times more reliable than the upper risk criterion. The upper and lower risk index criteria are the curves which determine the acceptable, undesirable and unacceptable region of risk index. The exhaust valve is a significant component since its risk index is higher than the lower risk criterion and is situated in the undesirable region. It has a significant basic failure effect (spindle malfunction $\Rightarrow$ exhaust valve failure $\Rightarrow$ accelerated deterioration of the valve seat) and consequently "bad combustion and decrease in cylinder power". According to the proposed model for adjustment of the maintenance approach of the exhaust valve by reducing the risk index decreasing the failure frequency in the component's lifetime, the preventive periodical maintenance and on-condition maintenance should be requested. Because of high predictability of the exhaust valve, preventive periodical maintenance is highly desirable, applying the mentioned maintenance at shorter intervals than suggested by the manufacturer and with an on-condition maintenance (inspection) and an acceptable reaction time. However, after a certain period of time it is necessary to repeat the cycle of adjustment of the maintenance approach for the exhaust valve and to compare the results (maintenance intervals, failure predictability, risk indices and the choice of maintenance approach).

The efforts for higher operability and navigation safety should move in the direction of periodic maintenance adjustment by choosing an efficient maintenance policy by reducing the risk indices of the significant ship engine and equipment components, using the operation data from the ship machinery daily reports. A periodic adjustment of the maintenance approach contributes to reducing costs in the ship's life cycle.

\author{
Dr. Sc. ANTE BUKŠA \\ E-mail: buksa@pfri.hr \\ Dr. sc. IVICA ŠEGULJA \\ E-mail: is@pfri.hr \\ Dr. sc. VINKO TOMAS \\ E-mail: tomas@pfri.hr \\ Sveučilište u Rijeci, Pomorski fakultet \\ Studenska 2, 51000 Rijeka, Republika Hrvatska
}

\section{SAŽETAK}

\section{PODEŠAVANJE PRISTUPA ODRŽAVANJA U SVRHU POVEĆANJA OPERATIVNOSTI I SIGURNOSTI PLOVIDBE BRODOM}

Podešavanjem pristupa održavanja značajnih komponenti brodskih strojeva i uređaja koristeći eksploatacijske podatke iz dnevnih izvještaja brodskog pogona postiže se veća operativnost i sigurnost plovidbe brodom. Predloženi model podešavanja pristupa održavanja sastoji se od analize operativnih podataka i analize rizika. Analiza rizika obuhvaća definiranje gornjeg $i$ donjeg kriterija rizika $i$ indeksa rizika. Ako je indeks rizika veći od kriterija donjeg rizika komponenta je značajna, odnosno, ako je indeks rizika manji od kriterija donjeg rizika komponenta je neznačajna $i$ ima prihvatljiv indeks rizika. Za svaku značajnu komponentu koja ima indeks rizika „nepoželjan“ ili „neprihvatljiv“ bira se efikasna politika održavanja. Verifikacija predloženog modela podešavanja pristupa održavanja temelji se na izvornim operativnim podacima porivnog stroja iz trinaestgodišnjeg vremenskog razdoblja. Rezultati istraživanja analize kvarova porivnog stroja pokazuje da je ispušni ventil najugroženija komponenta s najvećom stopom kvara. Upravo zbog toga predloženi model podešavanja pristupa održavanja je verificiran na uzorku ispušnog ventila. Predlaže se da nastojanja za veću operativnost i sigurnost plovidbe brodom moraju ići u smjeru povremenog podešavanja pristupa održavanja tj. izborom efikasne politike održavanja smanjenjem indeksa rizika značajnih komponenti brodskog pogona.

\section{KLUČNE RIJEČI}

podešavanje pristupa održavanja, analiza rizika, indeks rizika, kriterij donjeg rizika, kriterij gornjeg rizika, značajne komponente, plovidba brodom

\section{REFERENCES}

1. The failure mode presents discrepancy from the specification at the lowest level of functional decomposition. The exhaust valve failure mode can be the result of usage, poor lubrication, exhaust gases, water in fuel or quality of fuel. The failure mode/cause combinations FMCC of the exhaust valve due to the failure mode wearing of the bushing and valve causes basic effect of valve failure.

2. Cracking of the lubricating pipe TC (turbocharger).

3. Oil leakage into the rocker arm lubricating system.

4. Cracking the gasket in the oil pump pressure pipe. 


\section{LITERATURE}

[1] Vučinić, B.: MA - CAD, Maintenance Concept Adjust ment and Design, Delft, Faculty of Mechanical Engineering and Marine Technology, 1994

[2] Bukša A.: Modeliranje održavanja brodskog porivnog sustava, Sveučilište u Rijeci, Pomorski fakultet u Rijeci, Rijeka 2005

[3] Operating manual for diesel engines, Type 7L 400/500, Maschinenfabrik Augsburg-Nürberg Aktiengesellschaft D - 8900 Augsburg

[4] Dnevnici stroja MAN 7L 400/500, (Engine log-books) from 1982 to 1994
[5] Bukša A., Tudor M., Kralj P.: Analiza kvarova brodskih redundantnih sustava, Pomorstvo, Year/Vol.18, Rijeka 2004, pp. 111-120

[6] Yoski Ozaki: An Introduction to the ABS Guide for Propulsion Redundancy, Guide for Propulsion Redundancy, The Motor Ship, June 1997, pp. 101-112.

[7] Porchet, F.: Reliability - the proven, cost-effective way, The Motor Ship, The $18^{\text {th }}$ Annual Marine Propulsion Conference, Hamburg, 21-22 March 1996, pp. 23 - 31

[8] Krapp, R.: Why is increased redundancy needed, The Motor Ship, The $18^{\text {th }}$ Annual Marine Propulsion Conference, Hamburg, 21-22 March 1996, pp. 13 - 21 (Footnotes) 